\title{
Low pH impairs complement-dependent cytotoxicity against IgG-coated target cells
}

\author{
Ezequiel Dantas ${ }^{1}$, Fernando Erra Díaz ${ }^{1}$, Pehuén Pereyra Gerber ${ }^{1}$, Antonela Merlotti ${ }^{1}$, \\ Augusto Varese ${ }^{1}$, Matías Ostrowski ${ }^{1}$, Juan Sabatté ${ }^{1}$, Jorge Geffner ${ }^{1}$ \\ ${ }^{1}$ Instituto de Investigaciones Biomédicas en Retrovirus y SIDA (INBIRS), CONICET, Facultad de Medicina, Universidad de \\ Buenos Aires, Argentina
}

Correspondence to: Jorge Geffner, email: jorgegeffner@gmail.com

Keywords: complement, $\mathrm{pH}$, acidosis, cancer, rituximab

Received: March 19, $2016 \quad$ Accepted: September 20, 2016

Published: October 3, 2016

\section{ABSTRACT}

Local acidosis is a common feature of allergic, vascular, autoimmune, and cancer diseases. However, few studies have addressed the effect of extracellular pH on the immune response. Here, we analyzed whether low pH could modulate complementdependent cytotoxicity (CDC) against IgG-coated cells. Using human serum as a complement source, we found that extracellular pH values of 5.5 and 6.0 strongly inhibit CDC against either $B$ lymphoblast cell lines coated with the chimeric anti-CD20 mAb rituximab or PBMCs coated with the humanized anti-CD52 mAb alemtuzumab. Suppression of CDC by low pH was observed either in cells suspended in culture medium or in whole blood assays. Interestingly, not only CDC against IgG-coated cells, but also the activation of the complement system induced by the alternative and lectin pathways was prevented by low $\mathrm{pH}$. Tumor-targeting mAbs represent one of the most successful tools for cancer therapy, however, the use of mAb monotherapy has only modest effects on solid tumors. Our present results suggest that severe acidosis, a hallmark of solid tumors, might impair complement-mediated tumor destruction directed by mAb.

\section{INTRODUCTION}

Low values of extracellular $\mathrm{pH}$ are usually found in tumors and inflamed tissues. Interstitial acidification $(\mathrm{pH}$ 5.5-7.0) is associated with the course of inflammatory reactions against infectious agents in peripheral tissues [16]. Autoimmune and allergic diseases are also associated with the development of acidic microenvironments. In fact, patients with rheumatoid arthritis show low $\mathrm{pH}$ values in the synovial fluid of compromised joints (6.57.0 ), having the acidic $\mathrm{pH}$ being associated with synovial fluid leukocytosis and joint damage [7-9]. The lower airway of asthmatic patients also shows acidic values of extracellular $\mathrm{pH}$ during exacerbation of the disease. The $\mathrm{pH}$ of exhaled breath condensates from these patients is around 5.2, while healthy subjects showed values around $7.2[10,11]$. Local acidosis is a hallmark of tumor tissues. Values of extracellular $\mathrm{pH}$ ranging from 5.5 to 7.0 have been described in a number of solid tumors such as brain tumors, sarcomas, breast cancer, malignant melanoma, squamous cell carcinomas, and adenocarcinomas [12-16].
This acidic environment not only promotes local invasive growth and metastasis [17, 18], but also induces multidrug resistance due to the neutralization of weak base chemotherapeutic drugs [19].

Surprisingly, although it is widely appreciated that the immune response against pathogens, host antigens (autoimmunity) and tumor cells frequently occurs under acidic environments, not much is known about the influence of $\mathrm{pH}$ on the innate and the adaptive immune response. We have previously reported that low $\mathrm{pH}$ values induce the activation of neutrophils $[20,21]$ and conventional dendritic cells [22,23], suggesting that local acidification could be recognized by immune cells as a danger-associated molecular pattern (DAMP), stimulating the immune response. These results were confirmed later in two independent studies [24, 25]. Monocyte, NK cell and $\mathrm{T}$ cell functions were also shown to be regulated by low $\mathrm{pH}$ values, in the range 6.0-7.2 [26-28]. Moreover, acidic environments have shown to delay the rate of apoptosis in neutrophils, endothelial cells and tumor cells $[20,29,30]$. 
The constant fragment (Fc fragment) of $\mathrm{IgG}$ antibodies plays a crucial role in the induction of inflammatory and cytotoxic responses mediated by humoral and cellular components of the innate immune systems. The binding of IgG antibodies to their specific antigens can lead to the activation of the complement system, the induction of antibody-dependent cellular cytotoxicity (ADCC) and the phagocytosis of opsonized targets [31]. These mechanisms play an important role in antimicrobial immunity, autoimmunity, and host response against tumors [32, 33]. Moreover, they largely explain the therapeutic effects of mAbs used in cancer immunotherapy $[34,35]$. The influence of low $\mathrm{pH}$ on the ability of IgG antibodies to induce complement-mediated cytotoxicity (CDC) has not yet been characterized. In this study, we show that $\mathrm{pH}$ values similar to those found in solid tumors inhibit CDC induced by $\operatorname{IgG}$ antibodies.

\section{RESULTS}

\section{Low pH impairs complement-dependent cytotoxicity against IgG-coated target cells}

In a first set of experiments, we determined the concentration of the anti-CD20 chimeric antibody rituximab (RTX) needed to destroy Raji cells by complement. Using $10 \% \mathrm{HS}$ as a complement source, we found that $2 \mu \mathrm{g} / \mathrm{ml}$ of RTX induces the necrosis of 60 to $75 \%$ of Raji cells after $30 \mathrm{~min}$ of incubation, evaluated by PI staining and flow cytometry. A representative experiment is shown in Figure 1A. Increasing the concentration of HS to $50 \%$ did not further increase cytotoxicity (Figure 1B), hence to analyze the effect of extracellular $\mathrm{pH}$ on cytotoxicity we used $2 \mu \mathrm{g} /$ $\mathrm{ml}$ of RTX to coat Raji cells and 10\% HS as a complement source.

Figures $1 \mathrm{C}$ and $1 \mathrm{D}$ show that $\mathrm{pH} 5.5$ almost completely prevented CDC against Raji cells, while $\mathrm{pH}$ 6.0 reduced cytotoxicity by more than $50 \%$ compared with $\mathrm{pH}$ 7.3. No cytotoxicity was observed when HS was decomplemented by heating at $56^{\circ} \mathrm{C}$ for $30 \mathrm{~min}$ (Figure 1C). Similar results were observed using the B lymphocyte cell line Daudi instead of Raji cells (Figure 1E) or when CDC assays were performed in $\mathrm{Ca}^{2+} / \mathrm{Mg}^{2+}$ supplemented veronal-buffered saline instead of RPMI 1640 medium (Figure 1F). The pH-dependence of CDC was also studied using an alternative approach to evaluate cell viability, a colorimetric method, instead of PI staining, based on the reduction of the tetrazolium compound [3-(4, 5-dimethylthiazol-2-yl)-5-(3-carboxymethoxyphenyl)-2(4-sulfophenyl)-2H-tetrazolium] to a formazan product by metabolically active cells. Consistent with the observations made by PI staining, we observed that low $\mathrm{pH}$ prevented Raji cell death evaluated by this alternative methodology (Figure 1G). Finally, to be sure that inhibition of CDC was not related to a diminished binding of RTX to Raji cells at low $\mathrm{pH}$ values, we analyzed the binding of RTX at pH
$7.3,6.5,6.0$, and 5.5. Figure $1 \mathrm{H}$ shows that low $\mathrm{pH}$ did not inhibit the binding of RTX. In fact, a significant increase in the binding of RTX to Raji cells was observed at $\mathrm{pH}$ $6.5,6.0$, and 5.5, compared to $\mathrm{pH} 7.3(\mathrm{p}<0.01, \mathrm{n}=4)$.

To validate the observations made in $\mathrm{B}$ cell lines to other cell types, we analyzed the effect of $\mathrm{pH}$ on $\mathrm{CDC}$ against PBMCs coated with the humanized anti-CD52 $\mathrm{mAb}$ alemtuzumab. All these experiments were performed using autologous serum. Preliminary experiments showed that $10 \mu \mathrm{g} / \mathrm{ml}$ of alemtuzumab saturated the PBMC's binding capacity, evaluated by flow cytometry (data not shown). Figures $2 \mathrm{~A}$ and $2 \mathrm{~B}$ show that $\mathrm{pH} 5.5$ almost completely impaired CDC, while $\mathrm{pH} 6.0$ significantly prevented cytotoxicity. No cytotoxicity was observed when HS was decomplemented by heating at $56^{\circ} \mathrm{C}$ for 30 min (Figure 2A). As expected, no inhibition in the binding of alemtuzumab to PBMCs was observed in the range of $\mathrm{pH}$ analyzed (Figure $2 \mathrm{C}$ ). Together, our results suggest that severe acidosis $(\mathrm{pH} 5.5$ and 6.0) prevents CDC irrespective of the nature of target cells.

\section{Low pH impairs complement-dependent cytotoxicity against IgG-coated target cells mediated by both the classical and alternative pathways of activation}

It is usually assumed that the destruction of IgGcoated target cells by complement is mediated through the activation of the classical pathway. However, studies published by Taylor's lab suggests a more complex picture, strongly dependent on the order in which the antibody and the complement source are added to target cells [36]. Working with B-cell lines treated with the antiCD20 mAbs RTX or ofatumumab, the authors reported that when B cells were first opsonized with antibodies in serum-free medium, washed, and then cultured with HS, $\mathrm{CDC}$ is mediated through the activation of the alternative pathway of complement. By contrast, when anti-CD20 mAbs were added to B cells already suspended in HS, cytotoxicity is mainly mediated by the classical pathway of activation (36). Consistent with this unexpected observation, we found that when PBMCs were first opsonized with alemtuzumab in serum free medium, and then incubated with HS (10\%), CDC was unaffected by the addition of $\mathrm{Mg} / \mathrm{EGTA}$, suggesting that cytotoxicity is mediated through the alternative pathway of activation. By contrast, when PBMCs were opsonized with alemtuzumab in the presence of HS (10\%), CDC was strongly inhibited by $\mathrm{Mg} / \mathrm{EGTA}$, suggesting that cytotoxicity is mediated through the classical pathway of activation (Figure 3A). Interestingly, $\mathrm{CDC}$ assessed under both experimental conditions was similarly inhibited by low $\mathrm{pH}$ (Figures 3B and $3 \mathrm{C}$ ), suggesting that acidosis prevents the activation of the alternative and classical complement pathways.

To further confirm that low $\mathrm{pH}$ inhibits both pathways, we analyzed the effect of $\mathrm{pH}$ on the ability 


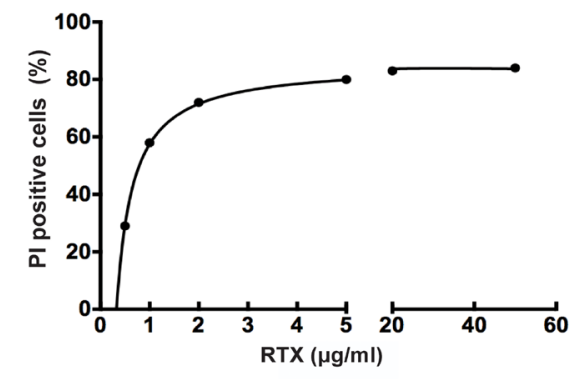

B

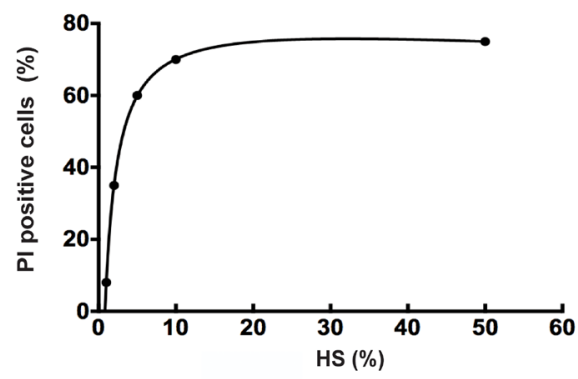

C

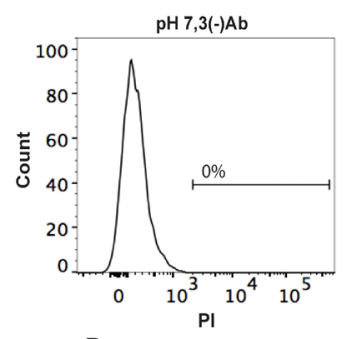

D

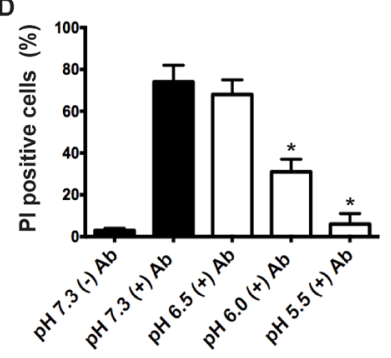

G

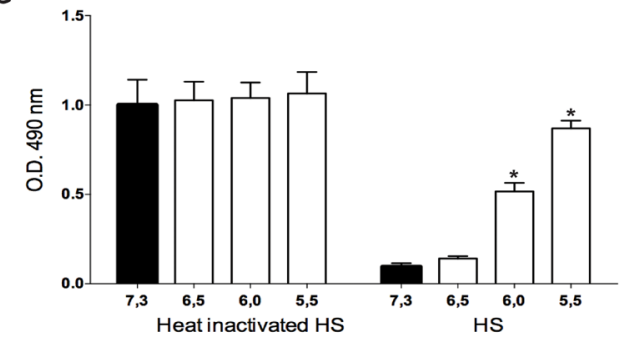

$\mathrm{pH} 7,3(+) \mathrm{Ab}$

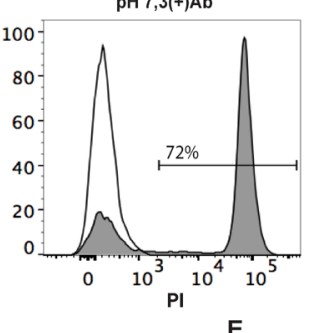

E

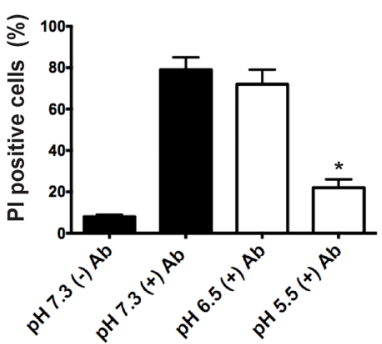

$\mathrm{pH} \mathrm{6,0(+)Ab}$
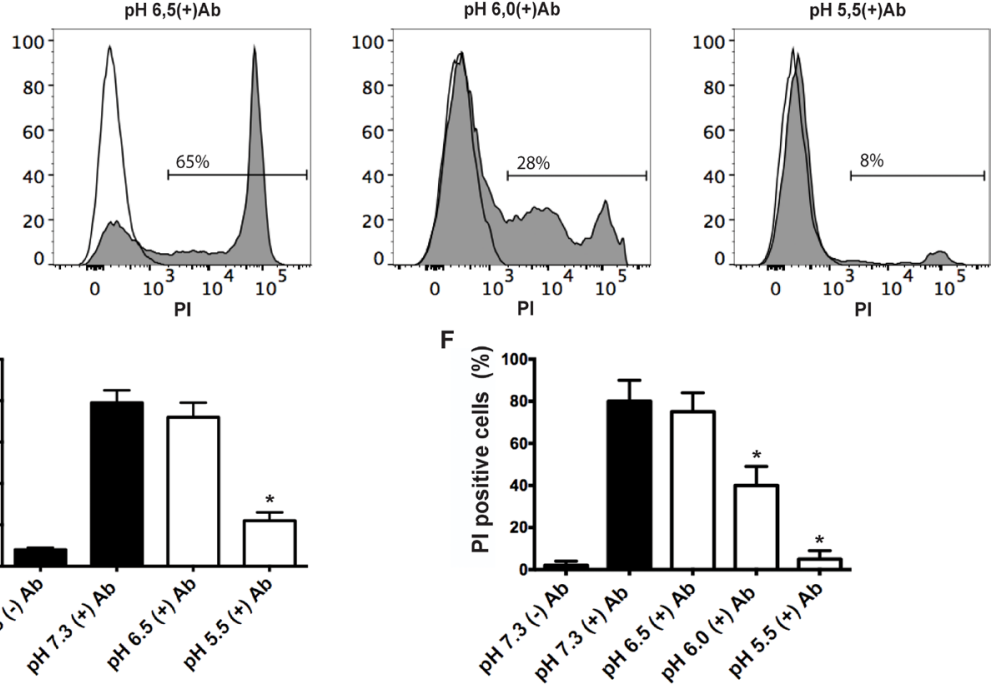

$\mathrm{H}$

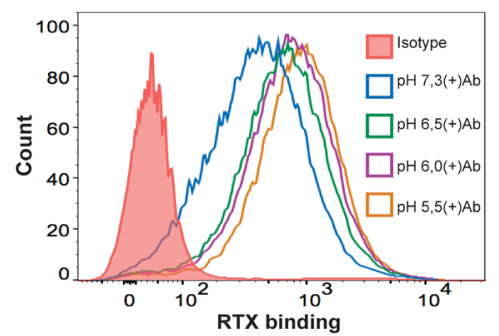

Figure 1: Low pH impairs CDC against RTX-coated B cell lines. A. Raji cells $\left(5 \times 10^{5} / 100 \mu 1\right)$ were treated with different concentrations of RTX $(0.5$ to $50 \mu \mathrm{g} / \mathrm{ml})$ and incubated for $30 \mathrm{~min}$ at $37^{\circ} \mathrm{C}$ and $\mathrm{pH} 7.3$, in RPMI medium supplemented with $10 \%$ of $\mathrm{HS}$. Necrosis was then evaluated by propidium iodide staining and flow cytometry. A representative experiment ( $\mathrm{n}=6)$ is shown. B. Raji cells $\left(5 \times 10^{5} / 100 \mu \mathrm{l}\right)$ were treated with $2 \mu \mathrm{g} / \mathrm{ml}$ of RTX and incubated in RPMI medium supplemented with different concentrations of HS ( 1 to $50 \%$ ) for $30 \mathrm{~min}$ at $37^{\circ} \mathrm{C}$ and $\mathrm{pH} 7.3$. Then, necrosis was evaluated. A representative experiment ( $\mathrm{n}=8$ ) is shown. $\mathbf{C}$ and $\mathbf{D}$. Raji cells $\left(5 \times 10^{5} / 100 \mu \mathrm{l}\right)$ were treated with RTX $(2 \mu \mathrm{g} / \mathrm{ml})$ and then were incubated in RPMI medium supplemented with untreated (grey histograms) or heat-inactivated HS (open histograms) $(10 \%)$ for $30 \mathrm{~min}$ at $37^{\circ} \mathrm{C}$, at different values of $\mathrm{pH}$. Then, necrosis was evaluated by propidium iodide staining and flow cytometry. Representative histograms and the mean \pm SEM of 5 experiments performed in duplicate are shown $(* \mathrm{p}<0.05$ vs $\mathrm{pH} 7.3+\mathrm{Ab})$. E. Daudi cells $\left(5 \times 10^{5} / 100 \mu \mathrm{l}\right)$ were treated with RTX $(2 \mu \mathrm{g} / \mathrm{ml})$ and then were incubated in RPMI medium supplemented with HS (20\%) for $30 \mathrm{~min}$ at $37^{\circ} \mathrm{C}$ at different values of $\mathrm{pH}$. Then, necrosis was evaluated by propidium iodide staining and flow cytometry. Data represent the mean \pm SEM of 4 experiments performed in duplicate $(*$ p $<0.05$ vs pH $7.3+\mathrm{Ab})$. F. Raji cells $\left(5 \times 10^{5} / 100 \mu \mathrm{l}\right)$ were treated with RTX $(2 \mu \mathrm{g} / \mathrm{ml})$ and then were incubated in $\mathrm{Ca}^{2+} / \mathrm{Mg}^{2+}$-veronal-buffered saline supplemented with $10 \% \mathrm{HS}$ for $30 \mathrm{~min}$ at $37^{\circ} \mathrm{C}$, at different values of $\mathrm{pH}$. Then, necrosis was evaluated by propidium iodide staining and flow cytometry. Data represent the mean \pm SEM of 4 experiments $(* \mathrm{p}<0.05 \mathrm{vs} \mathrm{pH} 7.3+\mathrm{Ab})$. G. Raji cells $\left(5 \times 10^{5} / 100 \mu \mathrm{l}\right)$ were treated with RTX $(2 \mu \mathrm{g} / \mathrm{ml})$ and then were incubated in RPMI medium supplemented with heat-inactivated or untreated HS $(10 \%)$ for 30 min at $37^{\circ} \mathrm{C}$, at different $\mathrm{pH}$ values. Then, cells were suspended in colourless RPMI and cell viability was analyzed using a colorimetric commercial kit based on the ability of viable cells to reduce a tetrazolium compound to a formazan product, which was quantified by absorbance at $490 \mathrm{~nm}$. Data represent the mean \pm SEM of 4 experiments performed in duplicate $(* \mathrm{p}<0.05 \mathrm{vs} \mathrm{pH} 7.3)$. H. Raji cells $\left(5 \times 10^{5} / 100 \mu \mathrm{l}\right)$ were incubated at room temperature for 30 min with RTX $(2 \mu \mathrm{g} / \mathrm{ml})$ in culture medium supplemented with $10 \%$ of heat-inactivated HS adjusted to different $\mathrm{pH}$ values. Then, cells were washed, and the binding of RTX to Raji cells was revealed using a FITC-labeled mAb directed to the Fc fragment of human IgG and flow cytometry. A representative experiment is shown $(n=4)$. 
of HS to destroy either IgG-coated SRBC or rabbit red blood cells suspended in medium supplemented with Mg-EGTA, the two hemolytic systems commonly used to evaluate the classical and alternative pathways of complement activation, respectively $[37,38]$. We found that pH 5.5 and 6.0 markedly inhibited CDC against IgGSRBC (Figure 3D). On the other hand, the lysis of rabbit red blood cells suspended in Mg-EGTA supplemented medium was shown to be significantly inhibited at $\mathrm{pH} 6.0$ and nearly completely abrogated at $\mathrm{pH} 5.5$ (Figure 3E). We conclude that low $\mathrm{pH}$ inhibits CDC mediated by both, the classical and alternative pathways of complement activation.

\section{Low pH impairs the generation of $\mathrm{C} 3 \mathrm{~b}, \mathrm{C} 4 \mathrm{~b}$ and C3a induced by IgG-coated target cells}

To further analyze the mechanisms underlying the ability of acidic $\mathrm{pH}$ to prevent CDC, we first determined whether the inhibition of cytotoxicity correlated with a reduced deposition of $\mathrm{C} 3 \mathrm{~b}$ on the surface of target cells. In these experiments, we used Raji cells (Figure 4A and 4C) and PBMCs (Figure 4B and 4C) opsonized in serum free medium with RTX or alemtuzumab, respectively. Opsonized cells were incubated for $30 \mathrm{~min}$ at $37^{\circ} \mathrm{C}$ in the presence of $10 \% \mathrm{HS}$ and the amount of $\mathrm{C} 3 \mathrm{~b}$ deposited on the cell surface was quantified by flow cytometry. Our results (Figure 4A-4C) show that low $\mathrm{pH}$ inhibited the generation/deposition of $\mathrm{C} 3 \mathrm{~b}$ on target cells. A similar inhibitory effect was observed when the deposition of $\mathrm{C} 4 \mathrm{~b}$ on alemtuzumab-coated PBMCs was examined (Figure 4D). Similar results were observed when PBMCs already suspended in $10 \%$ HS were opsonized with specific antibodies (data not shown).

We then looked at the effects of low $\mathrm{pH}$ on the production of $\mathrm{C} 3 \mathrm{a}$. In these experiments, autologous HS $(20 \%)$ was incubated with or without (controls) alemtuzumab-coated PBMCs for $30 \mathrm{~min}$, and the production of $\mathrm{C} 3 \mathrm{a}$ was then evaluated by ELISA. The results obtained are showed in Figure 4E. As previously described, incubation of HS alone leads to the "spontaneous" activation of complement and the generation of low levels of $\mathrm{C} 3 \mathrm{a}$, perhaps reflecting the activation of the classical pathway induced by physiological concentrations of serum immune complexes [39]. Consistent with the ability of $\mathrm{pH} 6.5$ to stimulate the alternative pathway of complement [40, 41], we found an enhanced generation of $\mathrm{C} 3 \mathrm{a}$ at this $\mathrm{pH}$ value. By contrast, a significant reduction in the generation of $\mathrm{C} 3 \mathrm{a}$ was observed when HS alone was incubated at $\mathrm{pH}$ 6.0 or 5.5. Working with alemtuzumab-coated PBMCs, on the other hand, we found that the production of $\mathrm{C} 3 \mathrm{a}$ was
A

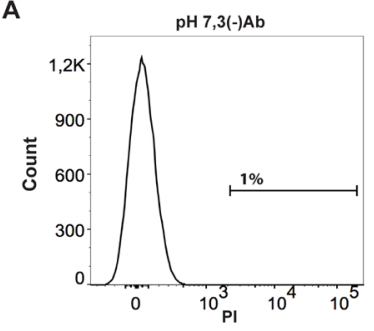

B

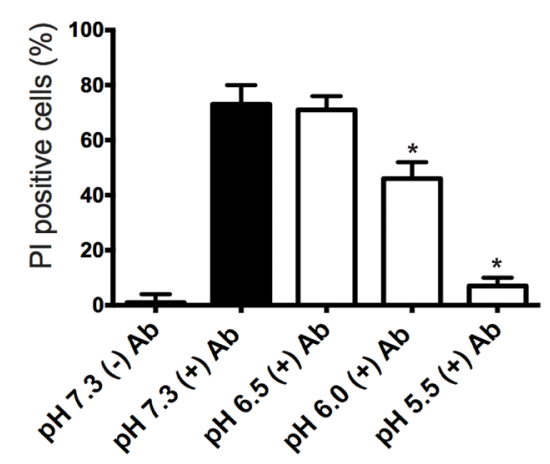

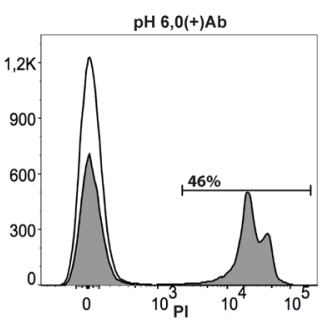

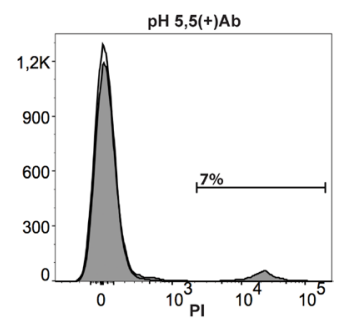

C

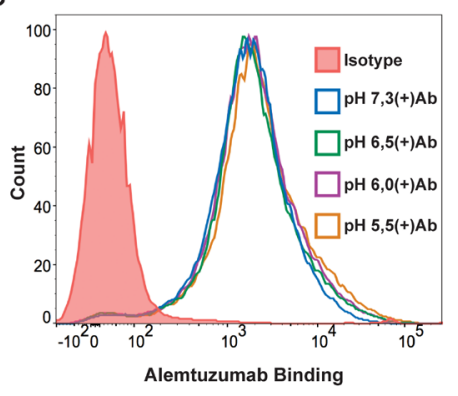

Figure 2: Low pH impairs CDC against alemtuzumab-coated PBMCs. A and B. PBMCs $\left(5 \times 10^{5} / 100 \mu 1\right)$ were treated with alemtuzumab $(10 \mu \mathrm{g} / \mathrm{ml})$ and then were incubated for $30 \mathrm{~min}$ at $37^{\circ} \mathrm{C}$ at distinct $\mathrm{pH}$ values in RPMI medium supplemented with $10 \%$ autologous HS. Necrosis was then evaluated by propidium iodide staining and flow cytometry. In (A), open histograms represent PBMCs treated with alemtuzumab $(10 \mu \mathrm{g} / \mathrm{ml})$ and incubated with $10 \%$ heat-inactivated autologous HS. Representative histograms (A) and the mean \pm SEM of 6 experiments performed in duplicate (B) are shown (* $\mathrm{p}<0.05 \mathrm{vs} \mathrm{pH} \mathrm{7.3).} \mathrm{C.} \mathrm{PBMCs}\left(5 \times 10^{5} / 100 \mu \mathrm{l}\right)$ were incubated for $30 \mathrm{~min}$ at room temperature with alemtuzumab $(10 \mu \mathrm{g} / \mathrm{ml})$ in culture medium supplemented with $10 \%$ of heat-inactivated autologous HS adjusted to different values of $\mathrm{pH}$. Then, cells were washed, and the binding of alemtuzumab to PBMCs was revealed using a FITC-labeled mAb directed to the Fc fragment of human IgG and flow cytometry. A representative experiment is shown $(n=3)$. 
significantly inhibited at $\mathrm{pH} 6.0$ and 5.5 compared with $\mathrm{pH}$ 7.3. In fact, the ability of alemtuzumab-coated PBMCs to induce the production of $\mathrm{C} 3 \mathrm{a}$ was completely abrogated at pH 5.5 (Figure 4E).

We then looked at the influence of low $\mathrm{pH}$ on the lectin pathway of complement activation. To this aim, HS $(20 \%)$ was incubated on mannan-coated plates for $30 \mathrm{~min}$ at $37^{\circ} \mathrm{C}$ and the production of $\mathrm{C} 3 \mathrm{a}$ was then evaluated by ELISA. Results in Figure $4 \mathrm{~F}$ show that $\mathrm{pH}$ values of 6.0 and 5.5 markedly prevented the enhancement in $\mathrm{C} 3 \mathrm{a}$ generation induced by mannan. Low $\mathrm{pH}$ also strongly inhibited the deposition of the factor $\mathrm{Bb}$ and $\mathrm{C} 3 \mathrm{~b}$ on the surface of the fungi Candida albicans (Figure 5A), a strong inducer of the alternative pathway of complement [42], as well as the deposition of C3b and C9 on the surface of Salmonella enterica (Figure 5B). Overall, our observations suggest that the three major pathways of complement activation are inhibited by low $\mathrm{pH}$ and that this inhibition might compromise not only the anti-tumor activity mediated by therapeutic antibodies, but also the microbicidal action of the complement system.

\section{Inhibition of $\mathrm{CDC}$ by low $\mathrm{pH}$ is a reversible phenomenon and occurs in whole blood}

Then, we analyzed whether the inhibition of CDC by low $\mathrm{pH}$ could be overcome upon $\mathrm{pH}$ neutralization. This was tested in a new set of experiments using alemtuzumabcoated PBMCs as target cells. Figures 6A and 6B show that abrogation of $\mathrm{CDC}$ by $\mathrm{pH} 5.5$ was almost completely reversed upon $\mathrm{pH}$ neutralization, suggesting that inhibition of CDC by low $\mathrm{pH}$ is a reversible phenomenon. Finally, we addressed the question as to whether, in the more physiologic milieu of whole blood, low $\mathrm{pH}$ could also
A

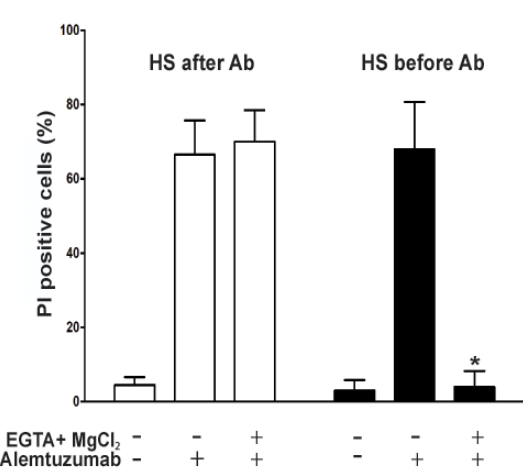

B

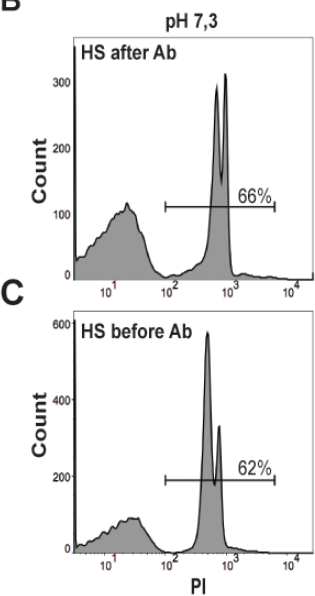

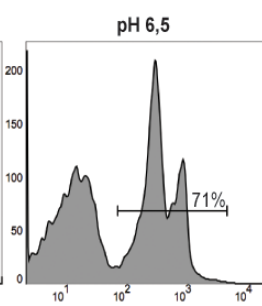
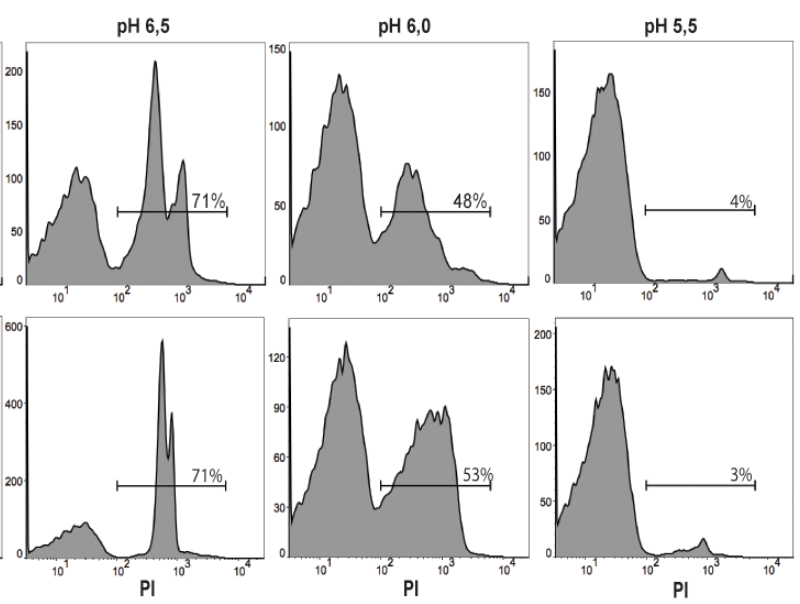

$\mathbf{E}$

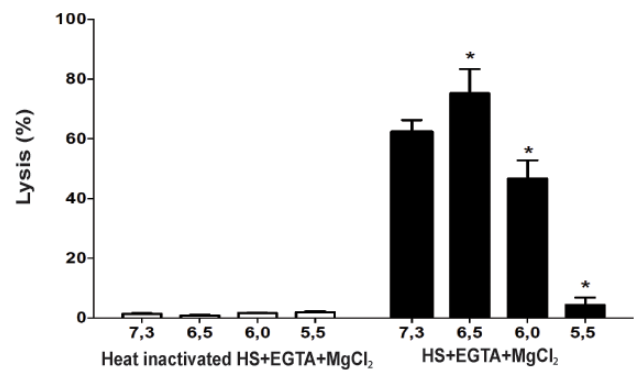

Figure 3: Low pH impairs CDC mediated by both the classical and alternative pathways of activation. A. Open bars: PBMCs $\left(5 \times 10^{5} / 100 \mu \mathrm{l}\right)$ were treated with alemtuzumab $(10 \mu \mathrm{g} / \mathrm{ml})$, washed and incubated for $30 \mathrm{~min}$ at $37^{\circ} \mathrm{C}$ and $\mathrm{pH} 7.3 \mathrm{with} \mathrm{RPMI}$ 1640 medium supplemented with $10 \% \mathrm{HS}$, in the absence or presence of $5 \mathrm{mM} \mathrm{MgCl}_{2}$ and $10 \mathrm{mM} \mathrm{EGTA}$ (EGTA/Mg). Black bars: PBMCs were suspended in RPMI 1640 medium supplemented with $10 \%$ HS $\left(5 \times 10^{5} / 100 \mu \mathrm{l}\right)$ and then were treated with alemtuzumab $(10 \mu \mathrm{g} /$ $\mathrm{ml}$ ). Cells were incubated for $30 \mathrm{~min}$ at $37^{\circ} \mathrm{C}$ and $\mathrm{pH} 7.3$, in the absence or presence of EGTA/Mg. In all cases, necrosis was evaluated by propidium iodide staining and flow cytometry. Data represent the mean $\pm \mathrm{SEM}$ of 4 experiments performed in duplicate. ${ }^{*} \mathrm{p}<0.05 \mathrm{vs}$ PBMCs incubated with alemtuzumab in the absence of EGTA/Mg. B. PBMCs $\left(5 \times 10^{5} / 100 \mu \mathrm{l}\right)$ were treated with alemtuzumab $(10 \mu \mathrm{g} /$ $\mathrm{ml}$ ), washed and incubated for $30 \mathrm{~min}$ at $37^{\circ}$ in RPMI 1640 medium supplemented with $10 \% \mathrm{HS}$, at different $\mathrm{pH}$ values. Necrosis was then evaluated by propidium iodide staining and flow cytometry. A representative experiment $(\mathrm{n}=4)$ is shown. C. PBMCs were suspended in RPMI 1640 medium supplemented with $10 \% \mathrm{HS}\left(5 \times 10^{5} / 100 \mu \mathrm{l}\right)$ and then were treated with alemtuzumab $(10 \mu \mathrm{g} / \mathrm{ml})$. Cells were incubated for $30 \mathrm{~min}$ at $37^{\circ} \mathrm{C}$ at different $\mathrm{pH}$ values, and necrosis was then evaluated by propidium iodide staining and flow cytometry. A representative experiment $(\mathrm{n}=5)$ is shown. D and $\mathbf{E}$. Hemolytic assays of classical (D) and alternative (E) pathways of complement activation were performed at different values of $\mathrm{pH}$ as described under Materials and Methods. Data represent the mean $\pm \mathrm{SEM}$ of 4-5 experiments performed in triplicate. ${ }^{*} \mathrm{p}<0.05 \mathrm{vs} \mathrm{pH} 7.3$. 
A
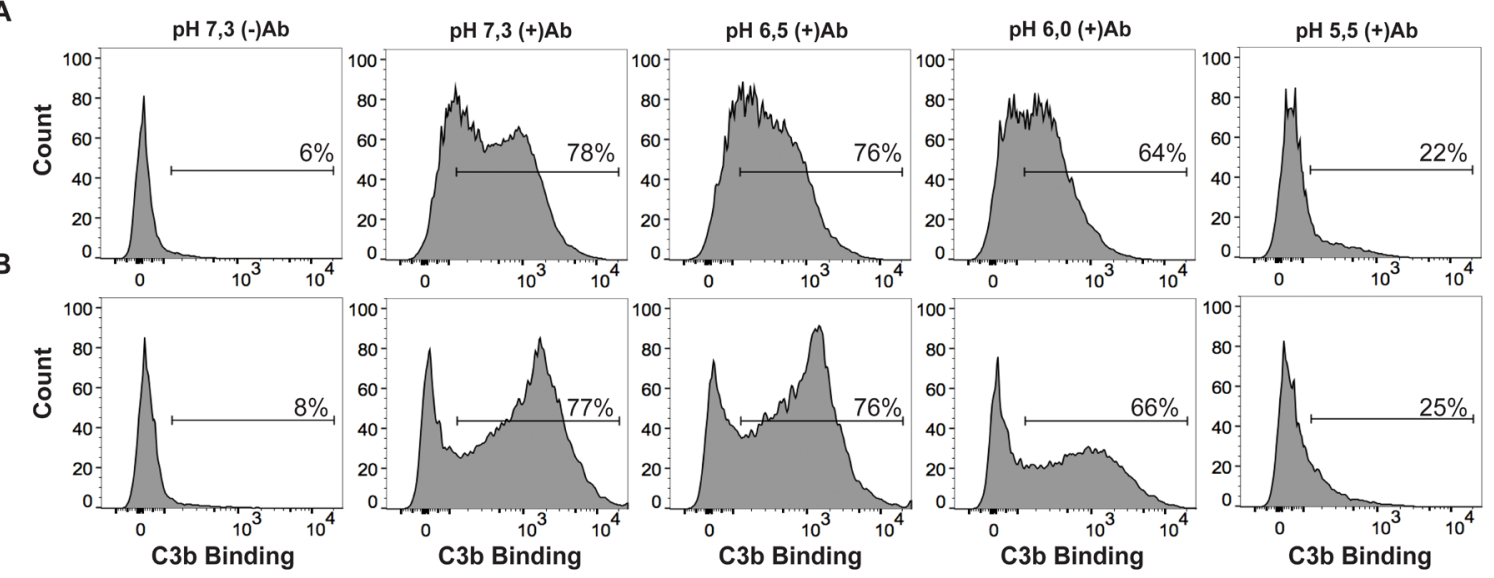

C

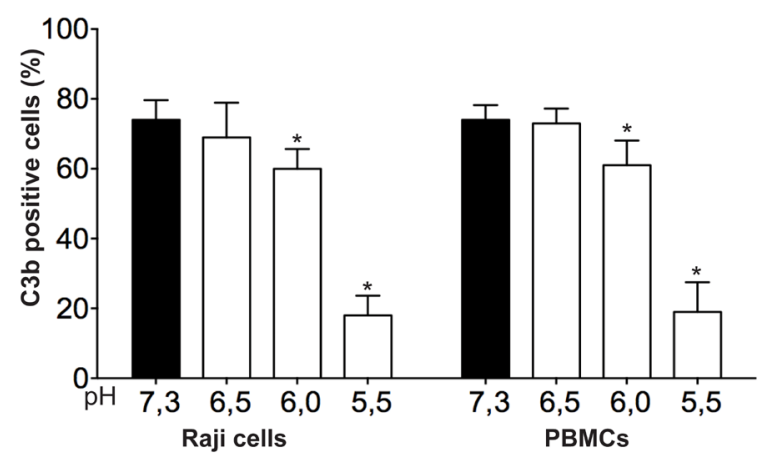

D
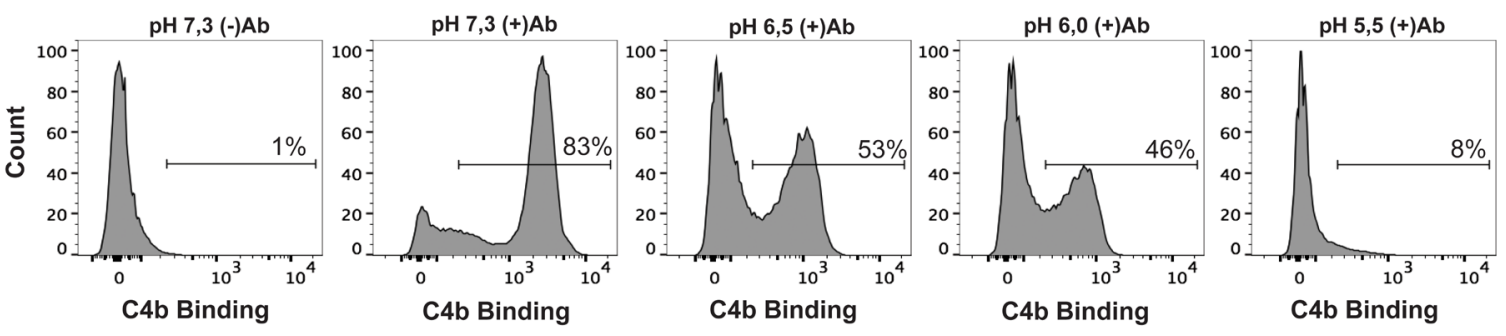

E
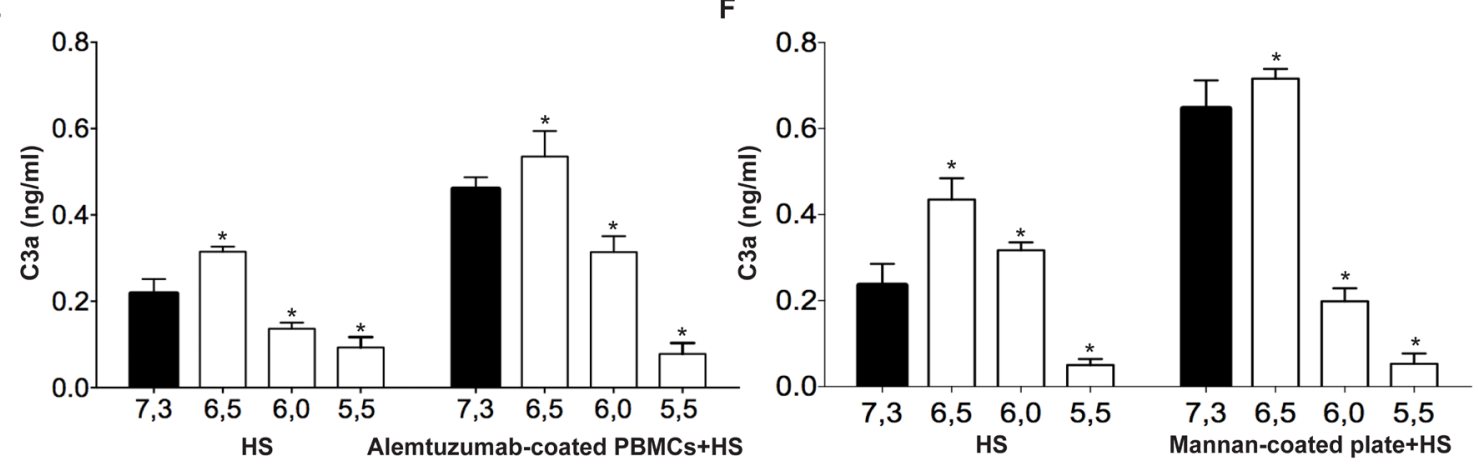

Figure 4: Low pH inhibits C3b, C4b and C3a generation. A-D. RTX-treated Raji cells $\left(5 \times 10^{5} / 100 \mu 1\right)$ and alemtuzumab-treated PBMCs $\left(5 \times 10^{5} / 100 \mu \mathrm{l}\right)$ were incubated in the presence of $10 \% \mathrm{HS}$ or $10 \%$ autologous $\mathrm{HS}$, respectively, for $30 \mathrm{~min}$ at $37^{\circ} \mathrm{C}$, at different $\mathrm{pH}$ values. Then, the amount of C3b deposited on Raji cells (A and C) and PBMCs (B and C) as well as the amount of C4b deposited on Raji cells (D) was determined using a FITC-labeled mAb directed to $\mathrm{C} 3 \mathrm{~b}$ or $\mathrm{C} 4 \mathrm{~b}$ and flow cytometry. Representative histograms and the mean \pm SEM of 5-7 experiments are shown $(* \mathrm{p}<0.05 \mathrm{vs} \mathrm{pH} \mathrm{7.3).} \mathrm{E.} \mathrm{HS}(20 \%)$ was incubated in the absence or presence of alemtuzumab-treated PBMCs $\left(5 \times 10^{5} / 100 \mu \mathrm{l}\right)$, for $30 \mathrm{~min}$ at $37^{\circ} \mathrm{C}$, at different $\mathrm{pH}$ values. Then, the concentration of $\mathrm{C} 3 \mathrm{a}$ in the culture medium was determined by ELISA. Values represent the mean \pm SEM of 4-5 experiments performed in duplicate (* $\mathrm{p}<0.05 \mathrm{vs} \mathrm{pH} 7.3)$. F. HS (20\%) was incubated on uncoated or mannan-coated plates for $30 \mathrm{~min}$ at $37^{\mathrm{a}} \mathrm{C}$, at different $\mathrm{pH}$ values. Then, the concentration of $\mathrm{C} 3 \mathrm{a}$ in the culture medium was determined by ELISA. Values represent the mean \pm SEM of 4 experiments performed in duplicate $(* \mathrm{p}<0.05 \mathrm{vS} p H 7.3)$. 
inhibit CDC. Whole blood assays were performed as previously described [43]. Preliminary experiments showed that consistent with the weak expression of CD52 by neutrophils [44], they were not susceptible to CDC induced by alemtuzumab in whole blood assays. By contrast, both T and B lymphocytes were shown to be highly susceptible to CDC (not shown). To evaluate the ability of low $\mathrm{pH}$ to suppress CDC, aliquots of whole blood $(100 \mu \mathrm{l})$ collected on either $3.2 \%$ sodium citrate (Figure $6 \mathrm{C}$ ) or the thrombin inhibitor bivalirudin $(50 \mu \mathrm{g} / \mathrm{ml})$ (Figure 6D), were adjusted to different $\mathrm{pH}$ values and treated with alemtuzumab (50 $\mu \mathrm{g} / \mathrm{ml}$ ) for $30 \mathrm{~min}$ at $37^{\circ} \mathrm{C}$. Then, the absolute number of viable CD3 $+\mathrm{T}$ cells was determined by flow cytometry. In agreement with the observations made in isolated PBMCs, we found that low $\mathrm{pH}$ markedly inhibited $\mathrm{T}$ cell depletion in assays performed in whole blood collected in either sodium citrate or bivalirudin. In fact, T cell depletion mediated by complement was significantly inhibited at $\mathrm{pH}$ 6.0 and almost completely prevented at $\mathrm{pH} 5.5$ (Figures $6 \mathrm{C}$ and $6 \mathrm{D})$.

\section{DISCUSSION}

Using HS as a complement source, we here showed that severe acidosis ( $\mathrm{pH}$ values of 5.5 and 6.0) inhibits CDC against IgG-coated target cells. Almost identical results were observed using B-cell lines and normal PBMCs, suggesting that low $\mathrm{pH}$ inhibits $\mathrm{CDC}$ irrespective of the nature of target cells. Abrogation of CDC by low $\mathrm{pH}$ appears to be a reversible phenomenon since it was completely reversed upon $\mathrm{pH}$ neutralization. Our observations also indicate that extracellular acidosis is able to inhibit the three major pathways of complement activation and that this inhibition might compromise not only the anti-tumor activity mediated by therapeutic antibodies, but also the microbicidal action of the complement system which also take place at inflammatory environments usually characterized by low values of extracellular $\mathrm{pH}$ [1-6]. Interestingly, inhibition of CDC was observed not only using cell lines and isolated PBMCs as target cells, but also in the more physiologic milieu of whole blood, suggesting that low $\mathrm{pH}$ might compromise the function of complement not only in vitro but also in vivo.

Previous reports have analyzed the influence exerted by acidic values of $\mathrm{pH}$ on the alternative and lectin pathways of complement activation. Studies performed with isolated complement components have shown that the optimal $\mathrm{pH}$ for the initiation and amplification of the alternative pathway of complement is 6.4, perhaps reflecting an increased generation of both C3 and C5 convertases [40, 41, 45]. Acidic values of
A
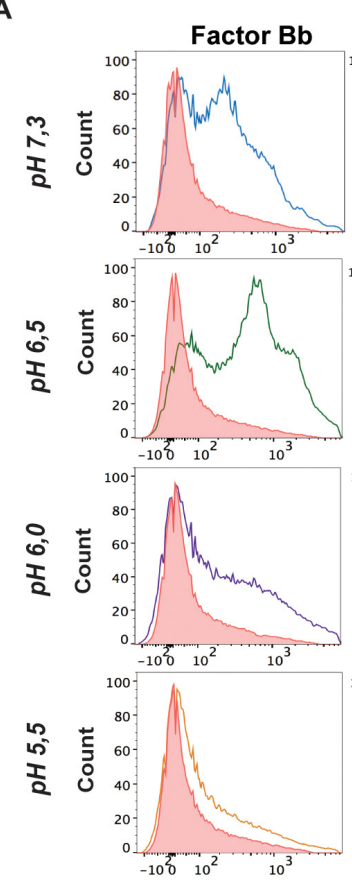
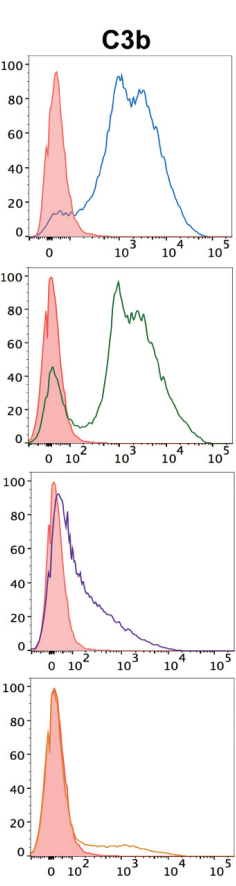
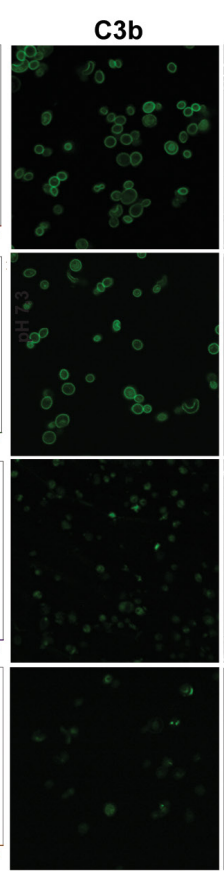

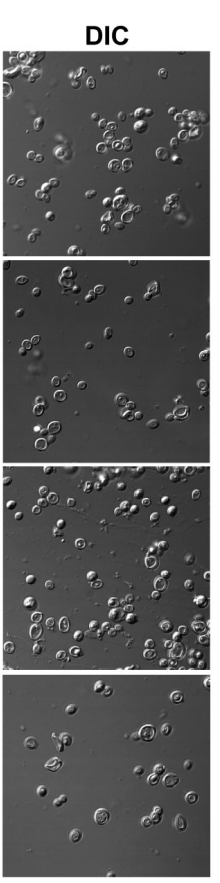

B
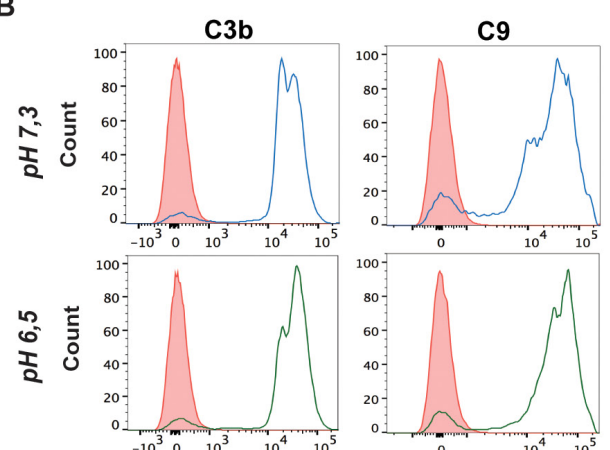

Figure 5: Low pH prevents C3b, factor Bb and C9 deposition on Candida albicans or Salmonella enterica. A. Candida albicans $\left(5 \times 10^{5} / 200 \mu \mathrm{l}\right)$ was incubated for $30 \mathrm{~min}$ in RPMI medium supplemented with untreated (open histograms) or heat-inactivated (filled histograms) HS (10\%), adjusted to different $\mathrm{pH}$ values. Yeasts were then washed and the deposition of C3b and factor Bb was analyzed by flow cytometry or fluorescence microscopy. B. Salmonella enterica serovar Enteritidis was incubated for $30 \mathrm{~min}$ at $5 \times 10^{6} / 200 \mu \mathrm{l}$ in RPMI medium supplemented with untreated (open histograms) or heat-inactivated (filled histograms) HS (10\%), adjusted to different $\mathrm{pH}$ values. Then $\mathrm{C} 3 \mathrm{~b}$ and $\mathrm{C} 9$ deposition on the bacterial surface was revealed by flow cytometry. Representative histograms or images from 4-7 experiments are shown. 
$\mathrm{pH}$ have also shown to modulate the ability of the acute phase reactant C-reactive protein (CRP) to activate the complement system. It is well known that CRP activates the classical pathway of complement upon reaction with phosphocholine-containing or polycation-containing ligands, and it has been shown that mildly acidic conditions (optimal $\mathrm{pH} \sim 6.3$ ) enables CRP to effectively activate complement even in the absence of these ligands [46]. Moreover, Zhang and coworkers [47] have reported that mild acidosis ( $\mathrm{pH} \mathrm{6.5)} \mathrm{favors} \mathrm{the} \mathrm{interaction} \mathrm{of} \mathrm{CRP}$ with a second acute phase reactant, L-ficolin, leading to an enhanced deposition of $\mathrm{C} 3$ on the bacterial surface, and an increased bactericidal activity of human serum.

$\mathrm{C} 1 \mathrm{q}$ is the key molecule required for the initiation of the classical pathway of complement activation. It

A

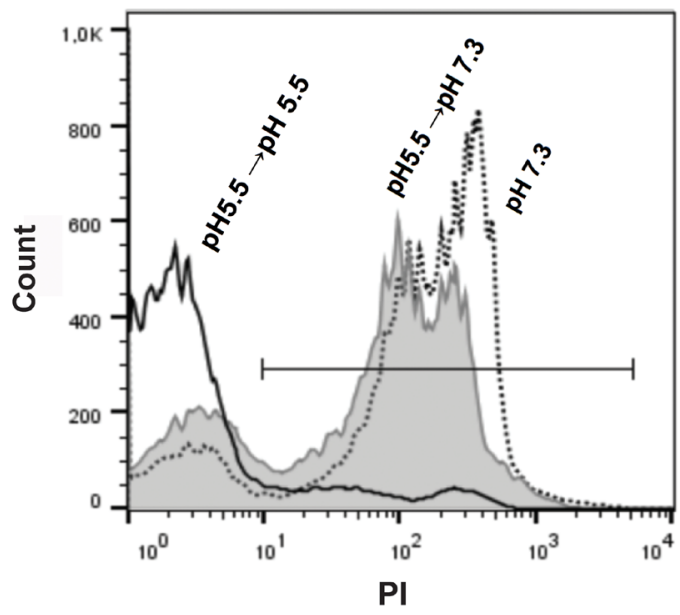

C

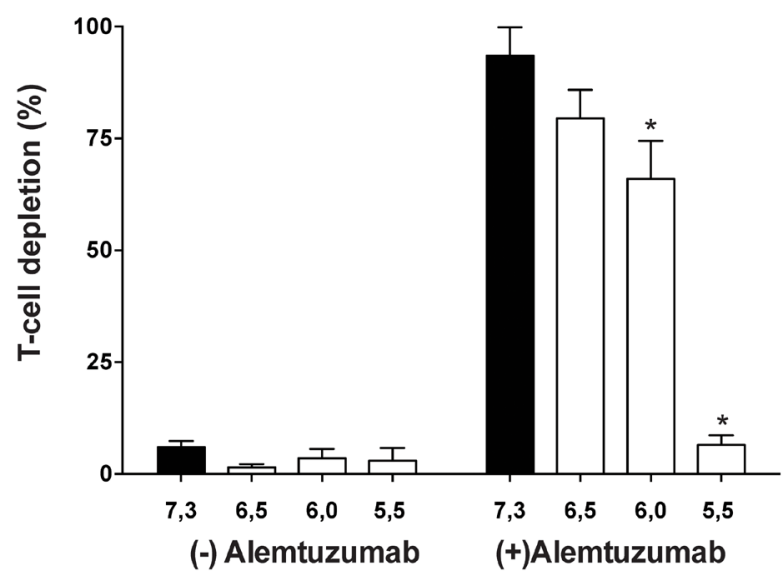

interacts with the $\mathrm{C} \gamma 2$ domain of $\operatorname{IgG}$ or the $\mathrm{C} \mu 3$ domain of $\operatorname{IgM}$ when these antibodies have recognized antigens, leading to the formation of immune complexes [48]. Previous studies have analyzed the influence exerted by low $\mathrm{pH}$ on the recognition of $\mathrm{IgG}$ by $\mathrm{C} 1 \mathrm{q}$, however, contrasting results have been reported. Using immobilized human IgG as an immune complex model, Kaul and Loos [49] have reported that the recognition of IgG by $\mathrm{C} 1 \mathrm{q}$ is lower at $\mathrm{pH} 6.5,6.0$, and 5.5, compared with $\mathrm{pH}$ 7.4. By contrast, using heat-aggregated human IgG1, Roumenina and coworkers [50] demonstrated that the recognition of $\mathrm{IgG}$ by $\mathrm{C} 1 \mathrm{q}$ shows an optimal $\mathrm{pH}$ of 5.5, and markedly decreases at neutral values of $\mathrm{pH}$. These contrasting results suggest that the effect exerted by $\mathrm{pH}$ on the activation of the classical pathway of complement
B

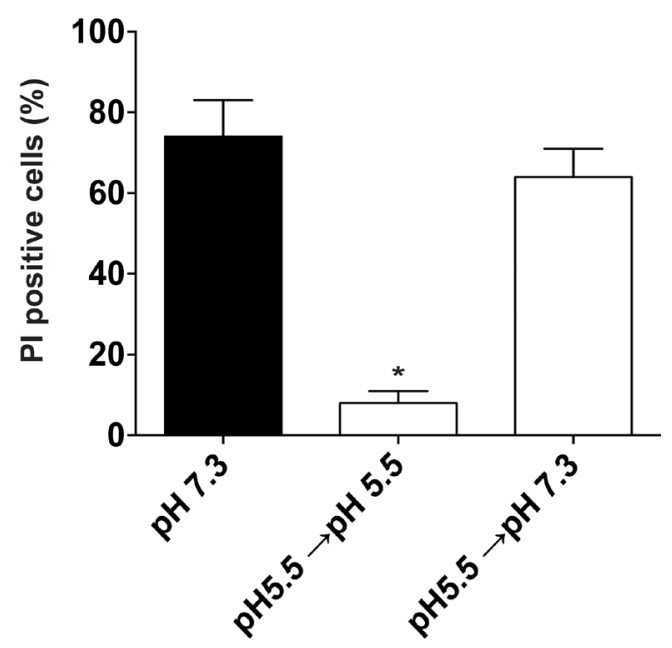

D

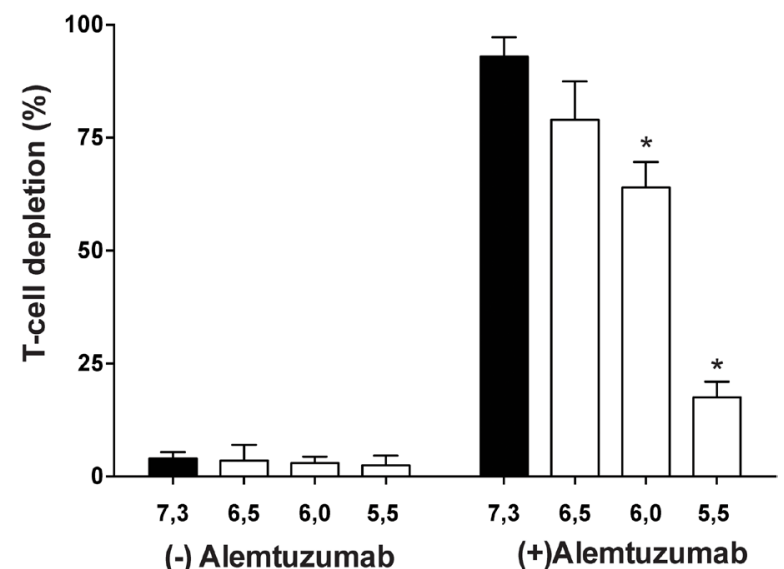

Figure 6: Inhibition of CDC by low pH occurs in whole blood and is a reversible phenomenon. A and B. Alemtuzumabtreated PBMCs $\left(5 \times 10^{5} / 100 \mu \mathrm{l}\right)$ were incubated for $30 \mathrm{~min}$ at $37^{\circ} \mathrm{C}$ with $10 \%$ autologous $\mathrm{HS}$, at $\mathrm{pH} 5.5$. Then, the $\mathrm{pH}$ was adjusted to $\mathrm{pH}$ 7.3 (grey histograms) or remained at $\mathrm{pH} 5.5$ (black line), and cells were further incubated for a period of 30 min at $37^{\circ} \mathrm{C}$. Finally, necrosis was evaluated by PI staining and flow cytometry. Controls represent alemtuzumab-treated PBMCs incubated for $60 \mathrm{~min}$ at $37^{\circ} \mathrm{C}$ and $\mathrm{pH} 7.3$ in the presence of $10 \%$ autologous HS (dotted lines). Representative histograms or the mean \pm SEM of 5 experiments are showed $(* \mathrm{p}<0.05$ vs pH 7.3). C and D. Aliquots of peripheral blood (100 $\mu$ l) collected on $3.2 \%$ sodium citrate $(\mathrm{C})$ or bivalirudin $(50 \mu \mathrm{g} / \mathrm{ml})(\mathrm{D})$ were adjusted to different $\mathrm{pH}$ values and treated with alemtuzumab $(50 \mu \mathrm{g} / \mathrm{ml})$. After $30 \mathrm{~min}$ incubation at $37^{\circ} \mathrm{C}$, cells were stained with FITC-conjugated anti-CD3 mAb and PerCP-7AAD. The percentage of CD3 ${ }^{+} / 7 \mathrm{AAD}^{-}$cells was determined for each condition and the results were expressed as the percentage of $\mathrm{T}$ cell depletion compared with untreated blood samples. Controls were made by incubating aliquots of peripheral blood, adjusted to different $\mathrm{pH}$ values, without alemtuzumab. Data represent the mean $\pm \mathrm{SEM}$ of $4-5$ experiments. ${ }^{*} \mathrm{p}<0.05 \mathrm{vs} \mathrm{pH} 7.3$. 
might be strongly influenced by the characteristics of the triggering stimulus. Not only the effector pathways of complement activation are susceptible to be modulated by $\mathrm{pH}$ in the range comprised between 5.0 and 7.5 , but also natural complement inhibitors have shown to act in a $\mathrm{pH}$-dependent manner. The ability of CR1 to promote the cleavage of $\mathrm{C} 3 \mathrm{~b}$ by factor I shows an optimum $\mathrm{pH}$ of 7.5 and decreases at $\mathrm{pH}$ values of 6.0 and 5.0. By contrast, the activity of factor $\mathrm{H}$ has been shown to be markedly higher at $\mathrm{pH} 5.0$ compared to $\mathrm{pH} 7.5$ [51] while the binding of factor $\mathrm{I}$ to either $\mathrm{C} 3 \mathrm{~b}$ or factor $\mathrm{H}$ reaches a maximum at $\mathrm{pH} 4.0$ to 5.5 , showing a sharp decrease at neutral $\mathrm{pH}$ values [52]. An enhanced ability of factor $\mathrm{H}$ to promote the cleavage of $\mathrm{C} 3 \mathrm{~b}$ by factor I might contribute to the inhibition of $\mathrm{CDC}$ by low $\mathrm{pH}$ observed in the present study.

The mechanism by which low $\mathrm{pH}$ impairs CDC is yet to be defined. The complement proteins $\mathrm{C} 3$ and C4 have an internal thioester which becomes available to react with amino or hydroxyl groups on the target surface upon activation [53]. This step plays a critical role in complement activation and appears to be strongly dependent on the presence of a single histidine residue (either in $\mathrm{C} 3$ or $\mathrm{C} 4$ ) which acts as a base or a nucleophile to attack the internal thioester, leading to the interaction of $\mathrm{C} 3 \mathrm{~b}$ and $\mathrm{C} 4 \mathrm{~b}$ with the target cell surface $[54,55]$. Because the imidazole side chain of histidine has a pKa of 6.0, we hypothesize that protonation of this histidine residue at $\mathrm{pH}$ values of 6.0 and 5.5 might impair its ability to attack the internal thioester, thus preventing both, the binding of $\mathrm{C} 3 \mathrm{~b}$ and $\mathrm{C} 4 \mathrm{~b}$ to the target cell surface and the assembly of $\mathrm{C} 3$ convertases. Further experiments are needed to test this hypothesis.

Strikingly, no previous studies have investigated the influence exerted by extracellular $\mathrm{pH}$ on the lysis of IgG-coated cells by complement. Because the recognized ability of $\mathrm{IgG}$-coated cells to activate the classical complement pathway, it has been assumed that the formation of the membrane attack complex (MAC) is mainly induced through the activation of the classical pathway and that the alternative pathway merely acts as a positive feedback amplification loop. This assumption is also consistent with the traditional view according to which the activation of the alternative pathway is considered to be antibody-independent. However, a number of studies have clearly shown that immune complexes can activate the alternative pathway of complement [56]. In line with these reports, and in agreement with previous observations made by Beum and coworkers in B cell lines opsonized with anti-CD20 antibodies [36], we found that the activation pathway responsible for CDC against alemtuzumab-opsonized PBMCs depends on the experimental conditions under which the assay is performed. When PBMCs were first opsonized with alemtuzumab in serum-free medium and then incubated with HS, CDC was shown to be unaffected by EGTA/Mg, suggesting that cytotoxicity is mediated through the activation of the alternative pathway. By contrast, when alemtuzumab was added to PBMCs already suspended in HS, CDC was abrogated by EGTA/Mg, suggesting the involvement of the classical pathway. The reasons underlying these differences are unclear, however, we found that $\mathrm{pH}$ values of 6.0 and 5.5 inhibited CDC assessed in both experimental conditions, reflecting the ability of severe acidosis to prevent the activation of the alternative and classical pathways of complement.

Cancer therapy based on the use of $\mathrm{mAb}$ is one of the most successful approaches for the treatment of patients with hematological malignancies and some solid tumors [57]. Mechanisms contributing to mAb-induced tumor cell death include CDC, antibody-dependent cellular cytotoxicity (ADCC), and induction of apoptosis by direct transmembrane signaling $[57,58]$. A large body of evidence suggests that CDC plays an important role in the therapeutic activity of some mAb [59]. C1q deficient mice show a poor response to $\mathrm{mAb}$-based therapies [60]. Patients with chronic lymphocytic leukemia suffer acute complement depletion upon administration of RTX, indicating an effective activation of complement in vivo [61]. Moreover, polymorphisms in complement components and complement regulatory factors have shown to be associated to the efficacy of immunotherapy $[62,63]$.

Our present results suggest that low values of extracellular $\mathrm{pH}$, similar to those found in solid tumors [12-16], might represent an important obstacle for mAb-based therapies because CDC would be impaired. Importantly, not only CDC, but also ADCC mediated by NK cells against IgG-coated tumor cells appears to be strongly inhibited by low $\mathrm{pH}[26,64]$, emphasizing that acidic microenvironments might limit the effectiveness of therapeutic mAb. This raises the question whether anti-tumor $\mathrm{mAb}$ could be combined with agents capable of raising tumor extracellular $\mathrm{pH}$ in order to improve the therapeutic effect. Interestingly, considering that acidic environments not only promotes tumor invasive growth and metastasis $[17,18]$, but also induces multidrug resistance due to the neutralization of weak base chemotherapeutic drugs [19], it has been suggested that manipulation of the extracellular $\mathrm{pH}$ might have considerable potential as cancer therapy [65]. In fact, preclinical studies have shown that proton pump inhibitors increase tumor extracellular $\mathrm{pH}$ and exert anti-tumor effects [66-67]. Interestingly, not only proton pump inhibitors but also mTOR inhibitors such as rapamycin or rapamycin analogues (rapalogs), used in the treatment of cancer $[68,69]$ have shown to decrease lactate production by tumor cells increasing extracellular $\mathrm{pH}$ [70]. Whether raising tumor extracellular $\mathrm{pH}$ by either proton pump inhibitors or rapamycin could improve the efficacy of mAb-based therapies in cancer patients is yet to be examined. 


\section{MATERIALS AND METHODS}

\section{Cells}

Peripheral blood mononuclear cells (PBMCs) were isolated from heparinized human blood samples by standard density gradient centrifugation on FicollHypaque, and resuspended in RPMI 1640 medium (Invitrogen Life Technologies) supplemented with the indicated concentration of autologous serum. The B cell lines Raji and Daudi were obtained from the American Type Culture Collection and cultured in RPMI 1640 medium supplemented with $10 \%$ heat-inactivated fetal calf serum, $50 \mathrm{U} / \mathrm{ml}$ penicillin, $50 \mu \mathrm{g} / \mathrm{ml}$ streptomycin, and $0.1 \mathrm{mM}$ nonessential amino acids (Invitrogen Life Technologies).

\section{Culture conditions}

Extracellular acidification was achieved by the addition of a precalculated volume of isotonic hydrogen chloride solution to either, the culture medium supplemented with HS or whole blood samples, as we had previously described [20]. In all cases, cell cultures were maintained at $37^{\circ} \mathrm{C}$ in a humidified atmosphere supplemented with $5 \% \mathrm{CO}_{2}$, and the $\mathrm{pH}$ was checked by using a pH meter (Jensen Instrument $\mathrm{Co}$ ).

\section{Complement-dependent cytotoxicity (CDC)}

Unless otherwise stated, CDC assays were performed as follows. The B lymphoblast cell lines Raji and Daudi, and human PBMCs were treated with the indicated concentrations of the chimeric anti-CD20 $\mathrm{mAb}$ rituximab (RTX) or the humanized anti-CD52 mAb alemtuzumab, respectively. Then, cells $\left(5 \times 10^{5} / 100 \mu \mathrm{l}\right)$ were incubated in RPMI 1640 medium supplemented with $10 \%$ human serum (HS), used as a complement source. Autologous HS was used in the assays performed with PBMCs. After $30 \mathrm{~min}$ of incubation at $37^{\circ} \mathrm{C}$ and different $\mathrm{pH}$ values, the percentage of necrotic cells was determined by propidium iodide (PI) staining and flow cytometry on a FACSCanto II instrument (BD Biosciences). In some experiments, $\mathrm{CDC}$ was assessed using cells suspended in $\mathrm{Ca}^{2+} / \mathrm{Mg}^{2+}$-supplemented veronal-buffered saline instead of RPMI medium. Moreover, CDC was also assessed using a colorimetric method to determine cell viability, instead of PI staining, based on the ability of metabolically active cells to reduce the tetrazolium compound [3-(4, 5-dimethylthiazol-2-yl)-5-(3-carboxymethoxyphenyl)-2(4-sulfophenyl)-2H-tetrazolium] to a formazan product (CellTiter 96 aqueous one solution cell proliferation assay kit, Promega).

In all cases, inactivation of HS was induced by heating at $56^{\circ} \mathrm{C}$ for $30 \mathrm{~min}$. When indicated the CDC assay was performed as follows: PBMCs were first suspended in RPMI 1640 medium supplemented with $10 \%$
HS $\left(5 \times 10^{5} / 100 \mu \mathrm{l}\right)$, and the anti-CD52 $\mathrm{mAb}$ alemtuzumab was then added, in the absence or presence of $\mathrm{MgCl}_{2}(5 \mathrm{mM})$ and EGTA $(10 \mathrm{mM})(\mathrm{Mg}$-EGTA). Cells were incubated for $30 \mathrm{~min}$ at $37^{\circ} \mathrm{C}$ at different $\mathrm{pH}$ values and the percentage of necrotic cells was determined by propidium iodide (PI) staining and flow cytometry. To analyze whether the inhibitory effect induced by low $\mathrm{pH}$ on $\mathrm{CDC}$ was reversible, alemtuzumab-coated target cells $\left(5 \times 10^{5} / 100 \mu \mathrm{l}\right)$ were first incubated with RPMI 1640 medium supplemented with $10 \% \mathrm{HS}$ for $30 \mathrm{~min}$ at $\mathrm{pH} 5.5$. Then, the $\mathrm{pH}$ of the culture medium was neutralized by the addition of isotonic $\mathrm{NaOH}$, and cells were further incubated for $30 \mathrm{~min}$ at $\mathrm{pH}$ 7.3. After this time, necrosis was evaluated as described above. Controls were carried out by incubating alemtuzumabcoated target cells for $60 \mathrm{~min}$ at $\mathrm{pH} 7.3$ or 5.5 .

\section{Hemolytic assays of classical and alternative pathways of complement activation}

Assays were performed as previously described with minor modifications $[37,38]$. Briefly, hemolytic assay for evaluation of the classical pathway of complement activation was performed using $5 \times 10^{7}$ sheep red blood cells (SRBC) opsonized with rabbit IgG antibodies antiSRBC (Sigma-Aldrich). Cells were suspended in RPMI 1640 medium without phenol red supplemented with $10 \%$ HS and adjusted to different $\mathrm{pH}$ values, in a final volume of $100 \mu \mathrm{l}$. Cells were then incubated for $30 \mathrm{~min}$ at $37^{\circ} \mathrm{C}$. Then, cells were centrifuged and hemolysis was evaluated by measuring $\mathrm{OD}$ at $540 \mathrm{~nm}$. Blanks were prepared with $5 \times 10^{7}$ SRBC opsonized with rabbit IgG antibodies antiSRBC, suspended in RPMI 1640 medium without phenol red supplemented with $10 \%$ heat-inactivated HS and adjusted to different $\mathrm{pH}$ values, in a final volume of $100 \mu \mathrm{l}$. The OD of $5 \times 10^{7}$ SRBC lysed by the addition of $100 \mu \mathrm{l}$ of distilled water was taken as $100 \%$ lysis. In all cases, the absorbance of blank tubes was lower than $10 \%$ compared with the absorbance of the tubes with $100 \%$ lysis. The percentage of lysis for each experimental condition was calculated as follows: $\left[\mathrm{OD}_{540}(\mathrm{X})-\mathrm{OD}_{540}\right.$ (blank)]/[ $\mathrm{OD}_{540}$ $(100 \%)-\mathrm{OD}_{540}$ (blank)]/ x 100. The hemolytic assay for evaluation of the alternative pathway of complement activation was performed using $2.5 \times 10^{7}$ rabbit red blood cells suspended in RPMI 1640 medium without phenol red supplemented with $20 \% \mathrm{HS}, 5 \mathrm{mM} \mathrm{MgCl}_{2}$ and $10 \mathrm{mM}$ EGTA (Mg/EGTA) adjusted to different $\mathrm{pH}$ values, in a final volume of $100 \mu \mathrm{l}$. Cells were incubated for $30 \mathrm{~min}$ at $37^{\circ} \mathrm{C}$, centrifuged, and hemolysis was then evaluated by measuring OD at $540 \mathrm{~nm}$. The percentage of lysis for each experimental condition was calculated as described above.

\section{Analysis of $\mathrm{C} 3 \mathrm{~b}$ and $\mathrm{C} 4 \mathrm{~b}$ deposition on the surface of IgG-coated target cells}

Raji cells and PBMCs were treated with the antiCD20 mAb RTX $(2 \mu \mathrm{g} / \mathrm{ml})$ or the anti-CD52 $\mathrm{mAb}$ alemtuzumab $(10 \mu \mathrm{g} / \mathrm{ml})$, respectively, for $15 \mathrm{~min}$ at $37^{\circ} \mathrm{C}$. 
Then, cells $\left(5 \times 10^{5} / 100 \mu \mathrm{l}\right)$ were incubated for $30 \mathrm{~min}$ at $37^{\circ} \mathrm{C}$ in RPMI 1640 medium supplemented with $10 \%$ of $\mathrm{HS}$, at different values of $\mathrm{pH}$. After washing, $\mathrm{C} 3 \mathrm{~b}$ and/or $\mathrm{C} 4 \mathrm{~b}$ deposition on the cell surface was revealed by flow cytometry using specific FITC-labeled mAbs (AssayPro).

\section{Analysis of C3b, factor Bb, and C9 deposition on the surface of Candida albicans or Salmonella enterica}

Candida albicans (ATCC10231) was incubated for $30 \mathrm{~min}$ at a density of $5 \times 10^{5} / 200 \mu \mathrm{l}$ in RPMI medium supplemented with $10 \% \mathrm{HS}$, adjusted to different $\mathrm{pH}$ values. After washing, $\mathrm{C} 3 \mathrm{~b}$ and factor $\mathrm{Bb}$ deposition on the yeast surface was revealed by flow cytometry using specific FITC- or APC-labeled mAbs (AssayPro). Salmonella enterica serovar Enteritidis (\#5694) was incubated for $30 \mathrm{~min}$ at a density of $5 \times 10^{6} / 200 \mu \mathrm{l}$ in RPMI supplemented with $10 \%$ HS, adjusted to different $\mathrm{pH}$ values. After washing, $\mathrm{C} 3 \mathrm{~b}$ and $\mathrm{C} 9$ deposition on the bacterial surface was revealed by flow cytometry using specific FITC- or APC-labeled mAbs (AssayPro).

\section{Analysis of C3a generation induced by IgG- coated cells and mannan-coated plates}

HS (20\% in RPMI 1640 medium) was incubated for $30 \mathrm{~min}$ at $37^{\circ} \mathrm{C}$ with or without PBMCs $\left(5 \times 10^{5} / 100 \mu \mathrm{l}\right)$, previously treated with the anti-CD52 $\mathrm{mAb}$ alemtuzumab $(10 \mu \mathrm{g} / \mathrm{ml})$. Then, the presence of $\mathrm{C} 3 \mathrm{a}$ in the culture medium was analyzed by ELISA (Quidel).

To analyze the influence of low $\mathrm{pH}$ on the lectin pathway of complement activation we used mannancoated plates, as previously described [71]. Briefly, HS (20\%) was incubated for $30 \mathrm{~min}$ at $37^{\circ} \mathrm{C}$ in 96 well Nunc Maxisorb microtiter plates, uncoated or coated with $10 \mu \mathrm{g} /$ $\mathrm{ml}$ of mannan (Sigma-Aldrich). Then, the production of C3a was analyzed by ELISA.

\section{Measurement of complement-dependent cytotoxicity in whole blood}

It was performed as previously described [42]. Unmanipulated peripheral blood of healthy donors collected on either $3.2 \%$ sodium citrate or the specific thrombin inhibitor bivalirudin (Amuprux, Lab. Raffo, Argentina) $(50 \mu \mathrm{g} / \mathrm{ml})$, were adjusted to different $\mathrm{pH}$ values and treated with alemtuzumab, to a final concentration of $50 \mu \mathrm{g} / \mathrm{ml}$. Whole blood samples were incubated for $30 \mathrm{~min}$ at $37^{\circ} \mathrm{C}$, and then stained for $15 \mathrm{~min}$ at room temperature with FITC-conjugated anti-CD3 $\mathrm{mAb}$ and PerCP-7AAD (BD Biosciences). Samples were then lysed with a whole blood lysing solution (BD Biosciences) to eliminate red blood cells and analyzed by flow cytometry. The percentage of $\mathrm{CD}^{+} / 7 \mathrm{AAD}^{-}$cells was evaluated for each condition and the results were expressed as the percentage of $\mathrm{T}$ cell depletion compared with untreated blood samples. Controls were made by incubating aliquots of peripheral blood adjusted to different $\mathrm{pH}$ values without alemtuzumab.

\section{Statistical analysis}

Student's paired t test was used to determine the significance of differences between mean values, and $\mathrm{p}<0.05$ was determined to indicate statistical significance.

\section{ACKNOWLEDGMENTS}

We thank Maria Esther Dorado for her technical assistance.

\section{CONFLICTS OF INTEREST}

The authors declare no commercial or financial conflicts of interest.

\section{GRANT SUPPORT}

This work was supported by grants from the Consejo Nacional de Investigaciones Científicas y Técnicas, the Universidad de Buenos Aires (20020130100446BA), and the Agencia Nacional de Promoción Científica $\mathrm{y}$ Tecnológica (PICT 2012-2153) (Argentina).

\section{REFERENCES}

1. Dubos RJ. The micro-environment of inflammation or Metchnikoff revisited. Lancet. 1955; 1-5.

2. Edlow DW, Sheldon WH. The $\mathrm{pH}$ of inflammatory exudates. Proc. Soc. Exp. Biol. Med. 1971; 137:1328-1332.

3. Bryant RE, Rashad AL, Mazza JA, Hammond D. Lactamase activity in human pus. J. Infect Dis. 1980; 142:594-601.

4. Abbot NC, Spence VA, Swanson-Beck J, Carnochan FM, Gibbs JH, Lowe JG. Assessment of the respiratory metabolism in the skin from transcutaneous measurements of $\mathrm{pO} 2$ and $\mathrm{pCO} 2$ : potential for non-invasive monitoring of response to tuberculin skin testing. Tubercle. 1990; 71:15-22.

5. Simmen HP, Blaser J. Analysis of $\mathrm{pH}$ and $\mathrm{PO} 2$ in abscesses, peritoneal fluid, and drainage fluid in the presence or absence of bacterial infection during and after abdominal surgery. Am J Surg. 1993; 166:24-27.

6. Simmen HP, Battaglia H, Giovanoli P, Blaser J. Analysis of $\mathrm{pH}, \mathrm{pO} 2$ and $\mathrm{pCO} 2$ in draining fluid allows for rapid detection of infectious complications during the follow-up period after abdominal surgery. Infection. 1994; 22:386-389.

7. Ward TT, Steigbigel RT. Acidosis of synovial fluid correlates with synovial fluid leukocytosis. Am J Med. 1978; 64:933-936. 
8. Geborek P, Saxne T, Petterson H, Wollheim FA. Synovial fluid acidosis correlates with radiological joint destruction in rheumatoid arthritis knee joints. J Rheumatol. 1989; 16:468-472.

9. Mánsson B, Geborek P, Saxne T, Björnsson S. Cytidine deaminase activity in synovial fluid of patients with rheumatoid arthritis: relation to lactoferrin, acidosis, and cartilage proteoglycan release. Ann Rheum Dis. 1990; 49:594-597.

10. Hunt JF, Fang K, Malik R, Snyder A, Malhotra N, PlattsMills TAE, Gaston B. Endogenous airway acidification: implications for asthma pathophysiology. Am J Respir Crit Care Med. 2000; 161:694-699.

11. Ricciardolo F L, Gaston B, Hunt J. Acid stress in the pathology of asthma. J. Allergy Clin Immunol. 2000; 113:610-619.

12. Ashby BS. pH studies in human malignant tumors. Lancet. 1966; 2:312-315.

13. Tannock IF, Rotin D. Acidic $\mathrm{pH}$ in tumors and its potential for therapeutic exploitation. Cancer Res. 1989; 49:4373-4384.

14. Vaupel P, Kallinowsky F, Okunieff P. Blood flow, oxygen and nutrient supply, and metabolic microenvironment of human tumors: a review. Cancer Res. 1989; 49:6449-6465.

15. Justus CR, Dong L, Yang LV. Acidic tumor microenvironment and $\mathrm{pH}$-sensing $\mathrm{G}$ protein-coupled receptors. Front Physiol. 2013; 4:354.

16. Peppicelli S, Bianchini F, Calorini L. Extracellular acidity, a "reappreciated" trait of tumor environment driving malignancy: perspectives in diagnosis and therapy. Cancer Metastasis Rev. 2014; 33:821-832.

17. Estrella V, Chen T, Lloyd M, Wojtkowiak J, Cornnell HH, Ibrahim-Hashim A, Bailey K, Balagurunathan Y, Rothberg JM, Sloane BF, Johnson J, Gatenby RA, Gillies RJ. Acidity generated by the tumor microenvironment drives local invasion. Cancer Res. 2013; 73:1524-1535.

18. Wang L, Fan Z, Zhang J, Changyi Y, Huang C, Gu Y, $\mathrm{Xu} \mathrm{Z}$, Tang Z, Lu W, Wei X, Li C. Evaluating tumor metastatic potential by imaging intratumoral acidosis via $\mathrm{pH}$-activatable near-infrared fluorescent probe. Int J Cancer. 2015; 136:E107-E116.

19. Sauvant C, Nowak M, Wirth C, Schneider B, Riemann A, Gekle M, Thews O. Acidosis induces multi-drug resistance in rat prostate cancer cells (AT1) in vitro and in vivo by increasing the activity of the p-glycoprotein via activation of p38. Int J Cancer 2008; 123:2532-2542.

20. Trevani AS, Andonegui G, Giordano M, López DH, Gamberale R, Minucci F, Geffner JR. Extracellular acidification induces human neutrophil activation. J Immunol. 1999; 162:4849-4857.

21. Martínez D, Vermeulen M, Trevani A, Ceballos A, Sabatté J, Gamberale R, Alvarez ME, Salamone G, Tanos T, Coso OA, Geffner J. Extracellular acidosis induces neutrophil activation by a mechanism dependent on activation of phosphatidylinositol 3-kinase/Akt and ERK pathways. J Immunol. 2006; 176:1163-1171.

22. Vermeulen M, Giordano M, Trevani AS, Sedlik C, Gamberale R, Fernández-Calotti P, Salamone G, Raiden $\mathrm{S}$, Sanjurjo J, Geffner JR. Acidosis improves uptake of antigens and MHC class I-restricted presentation by dendritic cells. J Immunol. 2004; 172:3196-3204.

23. Martínez D, Vermeulen M, von Euw E, Sabatté J, Maggíni J, Ceballos A, Trevani A, Nahmod K, Salamone G, Barrio M, Giordano M, Amigorena S, Geffner J. Extracellular acidosis triggers the maturation of human dendritic cells and the production of IL-12. J. Immunol. 2007; 179:1950-1959.

24. Owen JS, Baker PR, O'Flaherty JT, Thomas MJ, Samuel MP, Wooten RE, Wykle RL. Stress-induced plateletactivating factor synthesis in human neutrophils. Biochim Biophys Acta. 2005; 1733:120-129.

25. Tong J, Wu WN, Kong X, Wu PF, Tian L, Du W, Fang M, Zheng F, Chen JG, Tan Z, Gong F. Acid-sensing channel contributes to the effect of acidosis on the function of dendritic cells. J Immunol. 2011;186:3686-3692.

26. Loeffler DA, Juneau PL, Heppner GH. Natural killer-cell activity under conditions reflective of tumor-environment. Int J Cancer. 1991; 48:895-899.

27. Mendler AN, Hu B, Prinz PU, Kreutz M, Gottfried E, Noessner E. Tumor lactic acidosis suppresses CTL function by inhibition of $\mathrm{p} 38$ and JNK/c-Jun activation. Int J Cancer. 2012; 131:633-640.

28. Rajamaki K, Nordstrom T, Nurmi K, Akerman KE, Kovanen PT, Oorni K, Eklund KK. Extracellular acidosis is a novel danger signal alerting innate immunity via the NLRP3 inflammasome. J Biol Chem. 2013; 288:13410-13419.

29. Terminella C, Tollefson K, Kroczynski J, Pelli J, Cutaia M. Inhibition of apoptosis in pulmonary endothelial cells by altered $\mathrm{pH}$, mitochondrial function, and ATP supply. Am J Physiol Lung Cell Mol Physiol. 2002; 283: L1291-1302.

30. Ryder C, McColl K, Zhong F, Distelhorst CW. Acidosis promotes Bcl-2 family-mediated evasion of apoptosis: involvement of acid-sensing $G$ protein-coupled receptor Gpr65 signaling to Mek/Erk. J BiolChem. 2012; 287:27863-27865.

31. Guilliams M, Bruhns P, Saeys Y, Hammad H, Lambrecht $\mathrm{BN}$. The function of $\mathrm{Fc} \gamma$ receptors in dendritic cells and macrophages. Nat Rev Immunol. 2014; 14:94-108.

32. Ravetch JV, Bolland S. IgG Fc receptors. Annu Rev Immunol. 2001; 19:275-290.

33. Pincetic A, Bournazos S, DiLillo DJ, Maamary J, Wang TT, Dahan R, Fiebiger BM, Ravetch JV. Type I and type II Fc receptors regulate innate and adaptive immunity. Nat Immunol. 2014; 15:707-716.

34. Bakem JE, van Egmond $\mathrm{M}$. Fc receptor-dependent mechanisms of monoclonal therapy of cancer. Curr Top Microbiol Immunol. 2014; 382:373-392. 
35. Rogers LM, Veeramani S, Weiner GJ. Complement in monoclonal antibody therapy of cancer. Immunol Res. 2014; 59:203-210.

36. Beum PV, Lindorfer MA, Peek EM, Stukenberg PT, de Weers M, Beurskens FJ, Parren PW, van de Winkel JG, Taylor RP. Penetration of antibody-opsonized cells by the membrane attack complex of complement promotes $\mathrm{Ca}(2+)$ influx and induces streamers. Eur J Immunol. 2011; 41:2436-2446.

37. Herper BL, de Jong BA, Dekker B, Aerts PC, van Dijk H, Rijkers GT, van Velzen-Blad H. Hemolytic assay for the measurement of functional human mannose-binding lectin: a modification to avoid interference from classical pathway activation. J Immunol Meth. 2009; 343:61-63.

38. Harrison RA, Lachmann PJ. Complement technology. D. M. Weir, ed. Handbook of Experimental Immunology 39.1. Palo Alto, Blackwell Scientific Publications; 1986.

39. Manderson AP, Pickering MC, Botto M, Walport MJ, Parish CR. Continual low-level activation of the classical complement pathway. J Exp Med. 2001; 194:747-756.

40. Fischelson Z, Horstmann RD, Muller-Eberhard HJ. Regulation of the alternative pathway of complement by pH. J Immunol.1987; 138:3392-3395.

41. Emeis M, Sonntag J, William C, Strauss E, Walka MM, Obladem M. Acidosis activates complement system in vitro. Mediat Inflamm. 1998; 7:417-420.

42. Kozel TR, Weinhold LC, Lupan DM. Distint characteristics of initiation of the classical and alternative complement pathways by Candida albicans. Infect Immun. 1996; 64:3360-3368.

43. Bologna L, Gotti E, Da Roit F, Intermesoli T, Rambaldi A, Introna M, Golay J. Ofatumumab is more efficient than rituximab in lysing B chronic lymphocytic leukemia cells in whole blood and in combination with chemotherapy. J Immunol. 2013; 190:231-239.

44. Ambrose LR, Morel AS, Warrens AN. Neutrophils express CD52 and exhibit complement-mediated lysis in the presence of alemtuzumab. Blood. 2009; 114:3052-3055.

45. Kenawy HI, Boral I, Bevington A. Complement-coagulation cross-talk: a potential mediator of the physiological activation of complement by low pH. Front Immunol. 2015; 6:215.

46. Miyazawa K, Inoue K. Complement activation induced by human-C-reactive protein in mildly acidic conditions. J Immunol. 1990; 145:650-654.

47. Zhang J, Koh J, Lu J, Thiel S, Leong BS, Sethi S, He CY, Ho B, Ding JL. Local inflammation induces complement crosstalk which amplifies the antimicrobial response. Plos Pathog. 2009; 5: e1000282.

48. Arlaud GJ, Gaboriaud C, Thielens NM, Rossi V, Bersch B, Hernandez JF, Fontecilla-Camps JC. Structural biology of $\mathrm{C} 1$ : dissection of a complex molecular machinery. Immunol Rev. 2001; 180:136-145.
49. Kaul M, Loos M. Dissection of C1q capability of interacting with $\mathrm{IgG}$. Time-dependent formation of a tight and only partly reversible association. J Biol Chem. 1997; 272:33234-33244.

50. Roumenina LT, Ruseva MM, Zlatarova A, Ghai R, Kolev M, Olova N, Gadjeva M, Agrawal A, Bottazzi B, Mantovani A, Reid KB, Kishore U, Kojouharova MS. Interaction of C1q, C-reactive protein and pentraxin 3: mutational studies using recombinant globular head modules of human C1q A, B, and C chains. Biochemistry 2006; 45:4093-4104.

51. Sim E, Sim RB. Enzymatic assay of C3b receptor on intact cells and solubilized cells. Biochem J. 1983; 210:567-576.

52. Soames CJ, Sim RB. Interactions between human complement factor H, factor I and C3b. Biochem J. 1997; 326:553-561.

53. Pangburn MK, Muller-Eberhard HJ. Relation of putative thioester bond in $\mathrm{C} 3$ to activation of the alternative pathway and the binding of $\mathrm{C} 3 \mathrm{~b}$ to biological targets of complement. J Exp Med. 1980; 152:1102-1114.

54. Dodds AW, Ren XD, Willis AC, Law SK. The reaction mechanism of the internal thioester in the human complement component 4. Nature 1996; 379:177-179.

55. Law SK, Dodds AW. The internal thioester and the covalent binding properties of the complement proteins $\mathrm{C} 3$ and $\mathrm{C} 4$. Protein Sci. 1997; 6:263-274.

56. Ratnoff WD, Fearon DT, Austen FK. The role of antibody in the activation of the alternative complement pathway. Springer Semin Immunopathol. 1983; 6:361-371.

57. Sliwkowski MA, Mellman I. Antibody therapeutics in cancer. Science 2013; 341:1192-1198.

58. Villamor N, Montserrat E, Colomer D. Mechanisms of action and resistance to monoclonal antibody therapy. Semin Oncol. 2003; 30:424-433.

59. Rogers LM, Veeramani S, Weiner GJ. Complement in monoclonal antibody therapy of cancer. Immunol Res. 2014; 59:203-210.

60. Di Gaetano N, Cittera E, Nota R, Vecchi A, Grieco V, Scanziani E, Botto M, Introna M, Golay J. Complement activation determines the therapeutic activity of rituximab in vivo. J. Immunol. 2003; 171:1581-1587.

61. Kennedy AD, Beum PV, Solga MD, DiLillo DJ, Lindorfer MA, Hess CE, Densmore JJ, Williams ME, Taylor RP. Rituximab infusion promotes rapid complement depletion and acute CD20 loss in chronic lymphocytic leukemia. J Immunol. 2004; 172:3280-3288.

62. Charbonneau B, Maurer MJ, Fredericksen ZS, Zent CS, Link BK, Novak AJ, Ansell SM, Weiner GJ, Wang AH, Witzig TE, Dogan A, Slager SL, Habermann TM, et al. Germline variation in complement genes and event-free survival in follicular and diffuse large B-cell lymphoma. Am J Hematol. 2012; 87:880-885.

63. Racila E, Link BK, Weng WK, Witzig TE, Ansell S, Maurer MJ, Huang J, Dahle C, Halwani A, Levy R, Weiner 
GJ. A polymorphism in the complement C1qA correlates with prolonged response following rituximab therapy of follicular lymphoma. Clin Cancer Res. 2008; 14:6697-6703.

64. Fisher B, Muller B, Fisch P, Kreutz W. An acidic microenvironment inhibits antitumoral non-major histocompatibility complex-restricted cytotoxicity: implications for cancer immunotherapy. J Immunother. 2000; 23:196-207.

65. Fais S. Evidence-based support for the use of proton pump inhibitors in cancer therapy. J Transl Med. 2015; 13:368.

66. Luciani F, Spada M, De Milito A, Molinari A, Rivoltini L, Montinaro A, Marra M, Lugini L, Logozzi M, Lozupone F, Federici C, Iessi E, Parmiani G, Arancia G, Belardelli F, Fais S. Effect of proton pump inhibitors pretreatment on resistance of solid tumors to cytotoxic drugs. J Natl Cancer Inst. 2004; 96:1702-1713.

67. Fais S, De Milito A, You H, Qin W. Targeting vacuolar $\mathrm{H}^{+}$-ATPases as a new strategy against cancer. Cancer Res. 2007; 67:10627-10630.
68. Vignot S, Faivre S, Aguirre D, Raymond E. mTOR-targeted therapy of cancer with rapamycin derivatives. Ann Oncol. 2005; 16:525-537.

69. Blagosklonny MV. Immunosuppressants in cancer prevention and therapy. Oncoimmunology 2013; 2: e26961.

70. Leontieva OV, Blagosklonny MV. M(o)TOR of pseudohypoxic state in aging; rapamycin to the rescue. Cell Cycle 2014; 13:509-515.

71. Ali YM, Lynch NJ, Haleem KS, Fujita T, Endo Y, Hansen S, Holmskov U, Takahashi K, Stahl GL, Dudler T, Girija UV, Wallis R, Kadioglu A, Stover CM, Andrew PW, Schwaeble WJ. The lectin pathway of complement activation is a critical component of the innate immune response to pneumococcal infection. Plos Pathog 2012; 8:e1002793. 